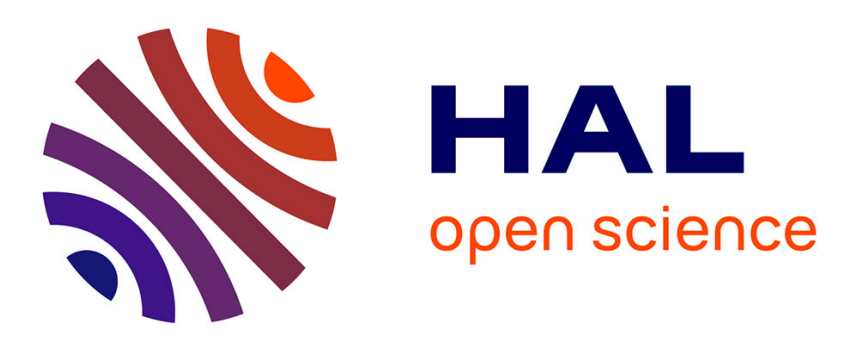

\title{
The emergence of complex sentences in a French child's language from $0 ; 10$ to 4;01: causal adverbial clauses and the concertina effect.
}

\author{
Martine Sekali
}

\section{- To cite this version:}

Martine Sekali. The emergence of complex sentences in a French child's language from 0;10 to 4;01: causal adverbial clauses and the concertina effect.. Journal of French Language Studies, 2012, 22 (1), pp.115-141. 10.1017/S0959269511000615 . halshs-00663388

\section{HAL Id: halshs-00663388 \\ https://shs.hal.science/halshs-00663388}

Submitted on 26 Jan 2012

HAL is a multi-disciplinary open access archive for the deposit and dissemination of scientific research documents, whether they are published or not. The documents may come from teaching and research institutions in France or abroad, or from public or private research centers.
L'archive ouverte pluridisciplinaire HAL, est destinée au dépôt et à la diffusion de documents scientifiques de niveau recherche, publiés ou non, émanant des établissements d'enseignement et de recherche français ou étrangers, des laboratoires publics ou privés. 


\title{
The emergence of complex sentences in a French
}

\section{child's language from 0;10 to 4;01: \\ causal adverbial clauses and the concertina effect.}

\author{
Martine Sekali \\ University of Paris Ouest Nanterre La Défense
}

\begin{abstract}
This article tests Diessel's 'integration' path of development of adverbial clauses (cf. Diessel, 2004), with special focus on the acquisition of 'causal' adverbial clauses, in the context of the overall development of grammatical/semantic complexification in a French child's longitudinal corpus of spontaneous speech (Madeleine, Paris Corpus) from 10 months to 4;01 years old. Three main patterns are retrieved in the child's uses of parce que constructions in interactional contexts. Linguistic analysis of these constructions reveals a dynamic pattern of syntactic expansion, integration and diversification, here called the concertina effect, which may provide an insight into the cognitive and pragmatic motives for syntax development in first language acquisition of French.
\end{abstract}

\section{KEYWORDS}

acquisition of complex sentences, adverbial clauses, parce que, causal domains, concertina effect 


\section{INTRODUCTION}

Complex sentences have been studied rather extensively in adult speech using various theoretical frameworks. Commonly, a complex sentence is defined as a multiple-clause sentence, i.e. a sentence composed of at least two verbs (or predicates) linked within a hierarchical complementing structure (subordination) or conjoined in a non-embedded structure (coordination). Subtypes of complex sentences are thus distinguished crosslinguistically: with on the one hand, finite/non finite complement clauses; relative clauses and adverbial clauses, and coordinated clauses linked by specific morphemes such as and, or and but (or equivalent morphemes in other languages) on the other hand. Recent work in pragmatics, cognitive linguistics, and more functionalist approaches (see for example Sweetser, 1990; Langacker, 1991; Cristofaro, 2003; Sanders 2005; Zufferey 2006; Sekali, 2010) have cast a new light on this issue. These studies have stressed the necessity to analyze and sub-categorize complex sentences, taking into account not only the syntactic, but also the semantic and pragmatic relations which are construed in complex 'constructions' taken as linguistic units paired with meaning. A study of the way children acquire, and spontaneously produce these constructions may provide an interesting insight into the nature of the link between the syntactic and semanticopragmatic levels in the process of complexification.

The most extensive and exhaustive study of the acquisition of complex sentences by children was made by Diessel (2004) on five English 
longitudinal corpora of spontaneous parent-child speech from $1 ; 8$ to $5 ; 1^{1}$, and his findings follow on from results presented in Tomasello (2003). Cross-linguistic studies have also been carried out on some specific complex structures (Clancy et al., 1976 on conjunctions in Turkish, Italian, English, and German; Clancy et al., 1986 on the processing of relative clauses by Korean, Japanese and English-speaking children), but a similarly comprehensive study on the acquisition of French complex sentences in children's spontaneous speech in longitudinal corpora remains to be done.

The purpose of this paper is twofold: first, to compare Diessel's results and conclusions on the paths of development of English complex sentences with our results based on a longitudinal corpus of French. The analysis is a case study based on Madeleine's data (Paris Corpus) from 0;10 to $4 ; 01^{2}$. Secondly, after a short comparison of the overall onset and development of syntactic complexification in the data, the study will focus in particular on the acquisition of the first adverbial clauses to appear, namely 'causal' adverbial clauses introduced with the subordinator parce que (because). Using Sweetser's domain categorization of causal clauses, we confront previous results on the acquisition of English and Dutch causals with our data. A cross-reference of the grammatical and semantic-pragmatic paths of complex construction development in Madeleine's data then leads us to consider the possible motivational link between the two.

\footnotetext{
${ }^{\mathbf{1}}$ For an overview of previous literature on this subject, see Bowerman, 1979 and O'Grady, 1997.

2 The collection and nature of Madeleine's data is detailed supra in the overall description of the corpora under investigation throughout this special issue.
} 


\section{THE ACQUISITION OF COMPLEX CONSTRUCTIONS IN ENGLISH:}

\section{DEFINITIONS AND RESULTS}

In Diessel (2004:41), complex sentences are defined in a usage-based functionalist approach as 'grammatical constructions that express a specific relationship between two or more situations in two or more clauses'. In this definition, the term 'situation' (which will be used in this study), refers to what Langacker (1991, chapters 4-5) calls 'processes' or 'states of affairs', which are usually encoded in clauses rather than noun phrases: 'a situation is a conceptual unit that has two important properties: situations are temporal and relational.' (Diessel, 2004:41). This definition is particularly useful, especially for the analysis of child speech, where language use is observed in its dynamic development and not as a set of definite (or predefined) structures. Constructions which in syntax are commonly considered as complex clauses because they contain two or more verbs in two or more clauses may thus be better regarded as simple when one of the clauses does not encode a real process or state of affairs but simply elaborates on a single situation. This is the case, for example, with complement clauses such as $I$ want to eat or Stop talking, where the matrix verbs want and stop do not express independent processes but function as modal or aspectual marks bearing on a single proposition.

Interestingly, Diessel (2004) shows that the acquisition of all types of complex constructions in English follows a common pattern, from lexicallyspecific constructions or conversational routines, to truly bi-clausal constructions expressing a relationship between two or more situations. Yet Diessel suggests two different paths of development in the acquisition of 
complex clauses according to subtypes. On the one hand, complement and relative clauses are acquired through a process of clause expansion from simple, non-embedded constructions (as in I want to eat), to 'more complex constructions where the matrix clause and the complement clause express a specific relationship between two independent states of affairs' (Diessel, 2004:73), as in You tell me what it is, for example. Adverbial and coordinate clauses on the other hand, proceed from the integration of two or more juxtaposed states of affairs into one grammatical unit. Diessel shows that in the acquisition of English, the earliest multiple-clause utterances produced by the children are juxtaposed clauses which suggest a semantic link that is not overtly expressed, such as in Hit the ball. Get it. Later, the conjunctions and and because are used, mainly to pragmatically combine utterances across speaker turns before they are used in truly 'bi-clausal constructions in which two clauses are integrated in a specific grammatical unit' (Diessel 2004:159), as in You push it and it goes up.

For this study, both of these conclusions were tested on the acquisition of French, through a case study of Madeleine's data.

\section{EMERGENCE OF COMPLEX CONSTRUCTIONS IN MADELEINE'S}

DATA

The present study analyses the data from the first filming session to the age of 4;01, (corresponding to transcripts available to date). This corresponds to a total number of 9,952 utterances produced by the child during the sessions. In order to track the child's first uses of complex utterances, all the transcripts were first analyzed for utterances containing more than one verb 
(leaving aside repetitions). All multi-clausal sentences were then checked in context and counted for each month. Figure 1 below shows the percentage of complex utterances over the total number of utterances each month.

\section{- $\quad$ Insert Figure 1 here -}

Early complex utterances appear at 1;11, and, as could be expected, the proportion of complex utterances increases rather spectacularly as the child grows older, up to about 50 percent of her utterances around the age of $3 ; 0$ (when her mean length of utterances (MLU) is 5.6) ${ }^{3}$.

From the adult perspective, and from a basic syntactic point of view, the French system of complex clauses is very similar to the English system, albeit with a few differences in tense and mode marking within the clauses. The same subtypes of multi-clause constructions can be found, namely finite/non-finite complement clauses, relative clauses, adverbial and coordinated clauses. These classical features and sub-type patterns of French complex structures were located and counted in order to give an initial overview of the order of emergence, distribution and development of complex utterances in the data. Figure 2 summarizes first appearance of early subtypes.

\section{- $\quad$ Insert Figure 2 here -}

The coding of the French data according to traditional syntactic subtypes shows that the order of emergence of complex structures is, on the whole, consistent with that observed in first language acquisition of English (Bowerman, 1979; Tomasello, 2003; Diessel, 2004), with a few differences in the order of the first appearances of certain conjunctions. In Madeleine's

\footnotetext{
${ }^{3}$ See the corpus description in the presentation of this issue.
} 
data, syntactic complexification starts with early occurrences of infinitive complement clauses at $1 ; 11$, closely followed at $2 ; 01$ by idiomatic cleft sentences (c'est moi qui / c'est maman qui) and non-finite intention clauses with pour + infinitive verb (pour pousser). At 2;03, relative clauses immediately follow the joint emergence of et (and) inter-clausal coordination and causal and conditional adverbial clauses in the order of appearance, and precede finite complement clauses and temporal adverbial clauses which appear at 2;04. As the child grows older, between 2;05 and $4 ; 01$, she uses other forms of coordination (mais (but), ou (or), donc and $d u$ coup (so)), and fronted causal adverbial clauses with puisque (since) and comme (as).

From a functional, more child centered perspective, it was necessary to analyze the way Madeleine actually used these constructions in context, and what function she gave them in her dynamic interaction with the adults. In order to do that, all complex utterances were observed in the co-text and situation of use. Several parameters were coded for a more fine-grained analysis of the child's uses of the various constructions:

- The 'co-text' of the constructions, i.e. types of verbs in the related clauses, regular co-occurrence of linguistic items, subject pronouns, discursive order of the links, semantic value and pragmatic function of the inter-clausal relationship.

- $\quad$ The relation to parental input and parental output; the semantic value and pragmatic function of multi-clausal constructions can be checked in the way the adult interprets the child's productions and reacts (the use of the video together with transcripts is a valuable tool here). 
Overall results show that, in child as in adult speech, complement constructions cannot be considered as complex constructions in our French corpus, because they never embed several situations, but only follow a pattern where the main clause actually expresses modalization of the complement clause as in sentences like, for example, je veux faire ça (I wanna do this) or je crois qu'il a faim (I think he's hungry) ${ }^{4}$. These results seem to imply that the earliest complex constructions (relating two or more situations) to be used by Madeleine are in fact adverbial and coordinated clauses, which appear jointly at the age of 2;02 (before relative clauses) with parce que (because), si (if) and et (and) conjunctions.

The order of emergence of conjoined clauses in Madeleine's data between $0 ; 10$ and 4;01 can be seen in Fig. 2 above. Leaving aside juxtaposition processes for this study, the data was coded for coordinating and subordinating conjunctions, yielding the following progression:

parce que (because), et (and), si (if)> quand (when) > mais (but), ou (or), donc, du coup (so), > jusqu'à ce que (until) >puisque (since) > comme (as) > après (after)

The distribution of conjunctions across the data is shown in Fig. 3, which highlights the importance of coordinators et and mais in Madeleine's use, as well as the prominent use of the subordinator parce que in adverbial constructions.

\section{- Insert Figure 3 here -}

The very early use $(2 ; 02)$ of causal adverbial clauses in our French data is consistent with previous studies on the acquisition of causals in

\footnotetext{
${ }^{4}$ The analyses leading to these conclusions cannot be developed here for reasons of space, but will be presented in another study.
} 
English (Kyratzis et al 1990; Diessel 2004), in Dutch (Evers-Vermeul and Sanders 2011), and in French (Zufferey 2006), but contradicts experimental studies (Clark 1971; Feagans 1980) which suggest, after Piaget 1948, that backward modification (which goes against the order-of-event principle) should be more difficult for children to understand and produce than constructions which follow the temporal and logical ordering of events (like donc and du coup (so) for example, which, in our data, appear later and in much smaller proportion, see Fig.3).

The discrepancy between experimental studies on children's comprehension and their actual production of these structures is probably due to the fact that children make different uses of these constructions in spontaneous speech. It should also be remarked that parce que (and because in English) do not necessarily construe causal or logical relations between clauses, even in adult speech, and that language cannot be identified with logical relations. In the forthcoming section, we therefore put special emphasis on the analysis of Madeleine's parce que clauses, and consider the interface between grammatical and semantic complexity.

\section{DEVELOPMENT OF CAUSAL ADVERBIAL CLAUSES IN MADELEINE'S DATA: THE CONCERTINA EFFECT}

The coding of parce que (because) adverbial clauses in the data shows a regular progression of its use from 2;02 (first appearance) to 4;01 (Fig. 4).

- Insert Figure 4 here - 
Naturally the number of parce que clauses used in each film session varies according to the type of activity that the little girl chooses to do (playing games, reading stories with her mother etc.), but it also varies with the type of interaction she has during the sessions. For example session 2;06 shows a rather low number of parce que clauses because Madeleine's older sister comes in and overpowers her in the conversation; while at 2;07 Madeleine plays a game with a little boy in a real peer-to-peer relationship, and the number of parce que rises to 51 in the hour-session. This in itself implies that inter-personal relations and subjective viewpoints may play an important part in the child's use of parce que in 'causal' adverbial clauses

\section{IV.1. Method}

Diessel (2004) reports from his comprehensive study of complex sentence acquisition in English, that the acquisition of all types of complex constructions in English follows a common pattern, from lexically specific constructions or conversational routines to truly bi-clausal constructions expressing a relationship between two or more situations. Yet he also differentiates the development path of complement and relative clauses and that of conjoined clauses (coordinate and adverbial), suggesting that conjoined clauses are not acquired through a process of clause expansion from simple, non-embedded constructions, but result from the 'integration of two or more independent situations into one grammatical unit'. The grammatical development path was tested on our corpus of French for causal adverbial clauses. All parce que constructions where first coded 
according to whether parce que 'integrated' several situations (or processes) into one multi-clausal grammatical unit, or elaborated on a single situation.

This functional approach to clause-combining involved linking grammatical complexity with semantic/pragmatic complexity, i.e. considering the linguistic level at which the connective operates (propositional content vs. modal/subjective endorsement). Sweetser's 'domain theory' (1990) offers a categorization of causal and conditional clause-combiners which is useful for such a coding, and which has been taken up and refined by many linguists (see in particular Evers-Vermeul and Sanders 2011). Three main 'domains' of use are distinguished, as defined and exemplified below with examples from our corpus:

- The CONTENT domain: the causal adverbial clause bears on the propositional content in the matrix clause and gives a cause for an event or state of affairs.

(1) MADELEINE-2;07: line 1985.

*MOT : ah pourquoi $\mathrm{t}(\mathrm{u})$ es pieds nus Madeleine ? [Madeleine how come you're barefoot?]

*CHI: parce que, parce que je suis pieds nus parce que j'ai enlevé mon collant. [Because, because, I'm barefoot because I took my tights off.]

(2) MADELEINE-2;09: line 1568.

${ }^{*} \mathrm{CHI}$ : tu vois il tient bien, il tombe pas parce que il est bien assis. [You see he's staying in place. He isn't falling because he's sitting down nicely.] 
- The SPEECH ACT domain: the causal clause bears on the speech act expressed in the matrix clause, and supports its illocutionary force.

(3) MADELEINE-2;04: line 1582.

*CHI: maman, va chercher de l'eau pour moi, parce que j'ai soif. [Mummy fetch me some water, because I'm thirsty.]

(4) MADELEINE -2;11: line 1737.

*CHI: tu peux m'aider à [/] hum à attraper un jeu ? parce que moi j'y arrive pas vraiment. [Can you help me get a game down? Because I can't really manage on my own.]

- $\quad$ The EPISTEMIC domain: the causal clause bears on the epistemic status of the assertion in the matrix clause, and gives an abductive argument supporting an inference, claim or belief expressed in the matrix clause;

(5) MADELEINE-2;09 : line 2981.

*CHI: il me mange pas ce loup, parce que, parce que c'est, c'est pas un vrai. [This wolf won't eat me, because he's not a real one.]

(6) MADELEINE-4 ;01: line 2543.

*CHI: ça doit être la chatte parce qu'au fond des oreilles elle a du rose. [It must be the girl-cat, because her ears are pink on the inside.] It is worth noting that the last two domains (speech act and epistemic) involve a 'causal' link which bear on the modus of the matrix clause rather than its dictum (or propositional content), and can therefore be categorized together as metalinguistic (or meta-representative, cf. Zufferey 2006). As a result, contrary to content parce que, which establishes a causal link between two situations, speech act and epistemic parce que do not link two situations. Rather, we can consider that speech act and epistemic causal 
clauses express one situation which serves as reinforcement of the root or epistemic modality expressed in the matrix clauses, as exemplified below.

In the coding and analysis of parce que constructions, we will thus cross Diessel's categorization of complex clauses with Sweetser's categorization of causal domains, in order to describe the grammatical integration path of development together with the semantic and functional path of development of such constructions across the data. This should enable us to test Diessel's 'integration path' as well as previous results on the order of acquisition of causal domains, and to discuss the potential link between grammatical integration and causal domain acquisition.

\section{IV.2. Results and analysis}

\section{IV.2.1. Early parce que clauses}

The earliest uses of parce que clauses by Madeleine are answers to pourquoi (why) causal questions, as in the following examples at 2;02:

(7) MADELEINE-2;02 : line 1795.

*MOT: oh mais pourquoi il va dans les toilettes ce doudou ? [Oh why is this teddy going to the toilets?]

*CHI: $p a(r) c(e)$ que il a fait. [Because he's done a poo.]

In this exchange, Madeleine produces a parce que construction which gives new information in response to a causal question. No matrix clause is expressed here, so that the utterance can hardly be considered a complex construction. Most of the first occurrences of parce que are thus associated to a previous question across speaker turns, in a conversational routine. Question and answer express two syntactically independent clauses which 
are combined only pragmatically in the dyadic exchange, and most of the time the semantic link bears on content. In Madeleine's speech, the premises of a complex construction appear with the use of the copula être (be) before the conjunction, which sets an anaphoric link between the mother's predication and her own:

(8) MADELEINE 2;02: line 1,751.

*CHI: (to her doll) tu veux aller dans ton lit ? (to her mother) Veut une couette. [D'you want to go to bed? Wants a quilt.]

*MOT: oui elle a une couette. Pourquoi elle a envie d'aller dans son lit? [Yes she has one. Why does she want to go to bed?]

*CHI: est parc(e) que veut dormir, elle veut un doudou. [포 because she wants to sleep, she wants a teddy.]

Interestingly, apart from the earliest uses, the number of parce que used by Madeleine is not always linked with the adult questioning her with pourquoi, as shown in Fig. 5.

- Insert Figure 5 here -

For one thing, Madeleine does not necessarily answer pourquoi with parce que, and, as grey bars in the graph show, she very quickly develops her own uses of parce que without being elicited by a pourquoi question, confirming that the conjunction can be used with a variety of functions (other than just the content causal function), and in a variety of contexts.

\section{IV.2.2. Domain distribution}

The content parce que also appears in Madeleine's data in the form of binary constructions [A parce que B], as in example (9) at 2;07: 
(9) MADELEINE-2;07: line 4487.

*CHI: elles sont tombées les feuilles [The leaves have fallen]

*OBS: oui [Yes]

*CHI: parce que c'est l'automne [because it's autumn.]

In this utterance, Madeleine observes facts, which she takes up after the observer's confirmation to express a cause to effect relationship between two independent situations (the leaves have fallen / it's autumn). This biclausal content relation, where clauses $\mathrm{A}$ and $\mathrm{B}$ have a $3^{\text {rd }}$ person subject and the parce que clause $\mathrm{B}$ explains the propositional content of $\mathrm{A}$, is far from being the most frequent.

- Insert Fig. 6 here -

The distribution of causal domain uses across the data (see Fig. 6) reveals that content-parce que clauses represent only $28 \%$ of parce que uses (including why-elicited parce que answers). The vast majority of parce que uses are speech act uses (63\%), while only $9 \%$ are epistemic uses. These results (and the rarity of epistemic uses) are globally consistent with previous studies made on English (Kyratsis et al 1990) and French (Zufferey 2006) longitudinal data. The order and development of domain acquisition in our French data is also consistent with the afore-mentioned studies, and presented in Fig.7.

-Insert Fig. 7 here-

As mentioned above, this distribution of causal domains is to be linked with the categorization of causal adverbial constructions in distinctive patterns according to their degree of grammatical integration. 
Observation of all occurrences of parce que adverbial clauses in the data reveals three main construction patterns, which will be exemplified and analysed in the following sections:

- $\quad$ the backward modalization pattern (where a single situation serves as reinforcement of the modality in the matrix clauses);

- the complex multi-clausal pattern (where two or more situations are embedded in an expanded construction);

- the bi-clausal integration pattern (where two situations are integrated in a relation of backward explanation).

The correspondence between the two orders of complexity is summed up in Fig. 8 .

- Insert Figure 8 here -

\section{IV.2.3 From expansion to integration}

\section{IV.2.3.1.The backward modalization pattern}

Several forms of parce que constructions follow this pattern, which overall represents $66 \%$ of the uses of parce que in the corpus (see Fig.13 below). The data contains many occurrences of parce que where the parce que clause contains a negation of non $\mathrm{A}$, in a sort of circular pattern: [A, because not non-A], as in, for example, at 2;04: On ferme parce que euh, hum, je, parce que on va pas ouvert (we're shutting it because, um, I, because we're not going to open). The circular pattern [A parce que $\mathrm{A}]^{5}$, is also significant

\footnotetext{
${ }^{5}$ The [A parce que A] construction, although often used in spontaneous speech, is usually
} not considered in studies on causality domains. 
in French children's speech, as shown in Morgenstern and Sekali (2009). Here is a typical example of this pattern in Madeleine's data:

(10) MADELEINE-2;05: line 2483.

*CHI: je tiens la grande pa(rce) que comme ça je la tiens [I'm holding the big one because that way I'm holding it.]

In both of these parce que constructions, despite the bi-clausal surface structure, the parce que clause adds modality but no content, so that only one situation is expressed, the adverbial clause marking pragmatic (or intersubjective) reinforcement of the 'matrix' clause.

As we have seen, in a majority of constructions (63\%), parce que adverbial clauses are used by Madeleine in order to reinforce the illocutionary force expressed by the assertive modality of the matrix clause rather than explain its content. This speech act linking function is an important feature of the parce que conjunction in child speech. Thus in example (11) below, at 2;07, the parce que adverbial clause bears on, and explains, the modus in the matrix clause (the imperative modality in donne moi) rather than the dictum (the propositional content), while in example (12) at 2;09, it justifies the injunction expressed by the interrogative mode in the matrix clause:

(11) *MOT: et toi tu apprends à écrire Madeleine ? [What about you, are you learning to write Madeleine?]

*CHI: donne moi le stylo parce que moi je sais écrire [Give me the pen, because $I$ know how to write.]

(12) *CHI: tu peux me l'habiller? [Can you dress her for me?]

*MOT: si tu veux [All right.] 
*CHI: parce que moi je sais pas me l'habiller [Because me, I can't dress her.]

In both cases, Madeleine uses parce que not to give a content-cause, but in order to justify a request retrospectively, and the adverbial clause encodes a single state of affairs (or situation) linked to the speech act expressed in the matrix clause.

This construction is quite often associated to the matrix verb faut, as in the following example, at 2;05, where Madeleine wants to gather all the pieces of a jigsaw puzzle and start a new one:

(13) MADELEINE-2;05: line 719.

*CHI: faut prendre tout parce qu'on va faire un autre puzzle! [We must pick them all up, because we're goin' to do another jigsaw puzzle!]

In this example, the parce que utterance serves as reinforcement of the deontic modal verb 'faut' in her request to change games.

Whether they are circular (A because A; A because not non A), or meta-linguistic (speech act links), the parce que adverbial clauses analyzed above are backward modifications, which do not link two independent situations. Although they are bi-clausal in syntactic structure, they cannot, in a more functional approach, be considered as complex constructions. Similarly to early complement constructions in our data, this pattern of adverbial clauses modalizes a single situation, but in a backward discursive movement rather than the forward movement construed in complement clauses. Importantly, the arguments introduced by these parce que clauses are not logical arguments but qualitative and subjective ones (or 
'motivational causes'), which serve to reinforce the root modality in the main clause. This phenomenon is clearly revealed by a strikingly frequent co-occurrence of the conjunction parce que with a paradigm of markers of subjective discordance, mainly: non (no), là (meaning here or now), and the first and second person pronouns moi or toi with a value of contrast. With parce que là, parce que moi etc., Madeleine refers to her present situation (highlighted as a contrastive landmark) as discordant with her expectations or wishes, and this justifies her actions or a desire for change expressed in the main clause:

\section{(14) MADELEINE-2;08}

*MOT: est-ce que tu veux bien m'apporter le petit lapin de Côme s'il te plait Madeleine? [Madeleine can you go and get Côme's bunny for me please?]

*CHI: mais non parce que là euh Sophie elle va dormir. [But I can't because now, hum, Sophie needs to go to bed.]

In this extract, Madeleine's mother asks her to get her brother's bunny, and Madeleine clearly reacts to her mother's request by refusing (with both non, mais, and then parce que là), because she wants to play with her doll called Sophie. The marker là serves as a situational landmark to express a discrepancy, in the present situation and from the child's viewpoint, between her mother's wishes and her own. We find the same use of the marker là in the following example:

(15) MADELEINE-2;08. Madeleine is making cookies with her mother. Her brother Côme has been crying for a while and her mother has to leave the room to feed him. 
CHI: Maman elle donne le lait à Côme parce que là il pleure. [Mummy's giving Côme some milk, because he's crying now.]

In the context of utterance, parce que enables her to explain that she is rather annoyed that her baby brother has been crying and disturbing her cooking. Là usually means 'here', 'there' or 'then' in French, but it can also serve (as is the case in examples (14) and (15)), to highlight the present situation of the speaker $\left[\mathrm{Sit}_{0}=\right.$ time, place and subjective origin of the utterance] in contrast with a personal wish. The argumentative pattern can be glossed as:

A, because, in my present situation [Sit ${ }_{0}$ ] B is bad, so A is necessary.

The frequent co-occurrence of parce que with the pronouns moi and toi marking contrast and discordance is also quite striking, as in the following dialogue at 2;08:

(16) MADELEINE-2;08

${ }^{*} \mathrm{CHI}$ : tu peux laver ma cuillère ? [Can you wash my spoon?]

*OBS: attention Madeleine [Careful Madeleine.]

*MOT: bon on va faire sans bicarbonate, hein, on va voir ce qui se passe [Oh well, we'll try without baking powder then, let's see what happens.]

*CHI: tu peux me [/] tu peux prendre ma cuillère parce que moi ... [Can you take my spoon because $I \ldots$ ]

Here Madeleine's mother, who is trying to sort out a recipe, doesn't react to the child's request. The utterance parce que moi does not even introduce a clause, but simply marks exasperation with the current state of affairs. The moi-landmark after the parce que conjunction could be interpreted as the 
beginning of a sentence that was not finished, but also as re-centrering the argument around the child's subjectivity taken as a landmark to express nonconformity of what is the case (the mother is talking to the observer) with what, from her viewpoint, should be the case (the mother should be answering Madeleine's request). The same thing goes for example (17), where Madeleine and another child are fighting over a toy:

(17) MADELEINE-2;07: line 1122.

*CHI: non ! c'est moi! tu m(e) $1(\mathrm{e})$ donnes parce que moi j'ai besoin d(e) faire encore le carré. [No, you give it to me ! because I need to do another square.]

Fig. 9 shows the percentage of co-occurrences of the parce que conjunction with this paradigm of situational discordance markers (là, moi/toi, mais non) coded throughout the data, which appears to be mainly close to, or above $50 \%$, and reaches up to $86 \%$ at $2 ; 08$ and even $100 \%$ at $2 ; 10$.

- Insert Figure 9 here -

The 'epistemic' use of parce que clauses is also part of the backward modalization pattern, in bi-clausal constructions where the parce que clause justifies a matrix clause that has an epistemic status expressing a claim or belief, as in examples (5) and (6), repeated below for reference:

(5) MADELEINE-2;09 : line 2981 (reading a book with her mother)

*CHI: il me mange pas ce loup, parce que, parce que c'est, c'est pas un vrai. [This wolf won't eat me, because he's not a real one.]

(6) MADELEINE-4 ;01: line 2543 (commenting on a picture) 
*CHI: ça doit être la chatte parce qu'au fond des oreilles elle a du rose. [It must be the girl-cat, because her ears are pink on the inside.]

It is important to note that, as in the case of speech act links, the domain of the link (or its target) is established by co-texual and situational parameters (modal verbs, tenses, assertive mode, verb types, discordance markers etc.) together with the conjunction, and not by parce que on its own. The epistemic status of the matrix clause is thus often construed by declarative verbs such as in je pense, je crois, or epistemic modal verbs such as doit (must) in (6). The present tense in (5) il me mange pas is given an epistemic status by Madeleine as she is explaining why she's not afraid of the wolf.

The epistemic use of parce que is cognitively more complex than speech act or content uses, because it implies backward modalization based on implicit predictive reasoning (I think it must be a girl-cat, because if it wasn't, its ears wouldn't be pink on the inside). This might explain the rarity of epistemic uses in our data and the fact that it develops later than speech act and content uses (as shown in Figs. 6 and 7). This late order of acquisition is an interesting phenomenon, which was also reported in the findings of Kyratzis et al (1990) for English, Evers-Vermeul and Sanders (2011) for Dutch, and Zufferey (2006) for French, and will be discussed further below.

One would expect that this first pattern of backward modalization of a single situation would gradually diversify, as the child gets older, into real bi-clausal complex constructions, via the path of development described by Diessel as the 'integration of two or more situations into a single 
grammatical unit'. Yet in the French data under consideration, an intermediate phase can be observed between speech act/epistemic metalinguistic uses of adverbial clauses, and bi-clausal content constructions expressing a causal link between two situations: the backward modalization pattern seems to expand to multi-clausal complex constructions where two or more situations are embedded mixing several link-domains, before integrating two situations into a simpler content-domain bi-clausal unit.

\section{IV.2.3.2. The complex multi-clausal pattern}

In Madeleine's data, real complex adverbial constructions appear at 2;04, not in the form of simple integrated structures, but in hyper-complex structures where several situations are expressed and linked in multi-slot constructions. In particular, there is a significant number (about $17 \%$ of the total number, see Fig.13) of occurrences of parce que adverbial clauses containing a second embedded conditional or temporal adverbial clause (mostly time fronted). In this pattern, parce que appears in co-occurrence mostly with sinon (otherwise), si (if) and quand (when or whenever). Here is one of the examples where the parce que clause contains a sinon-clause:

At 2;11, as OBS has just arrived at her house to film her, Madeleine is sitting in her garden, and says:

(18) MADELEINE-2;11

*CHI: ah mais c'est plutôt dans la maison qu'on filme [Oh but it's better to film indoors.]

*OBS: ah? C'est pas dehors ? [Oh? So it's not outside?] 
*CHI: parce que sinon on va attraper froid [Because otherwise we'll catch a cold.]

The general pattern of use is as follows: I think/want A, [because if not A, then B] (and I think B is bad). So the matrix clause $\mathrm{A}$ is pragmatically reinforced through the negative evaluation of the hypothetical consequences of non-A. The reasoning pattern is rather indirect, quite similar in form to a reductio ad absurdum sort of argument, but tinted with subjective evaluation.

The same double-embedding process also frequently appears with parce que si, with a negative form on the verb: A [parce que [si pas $\mathrm{A}-\mathrm{B}]]$, as in (19):

(19) MADELEINE-2;07

CHI: faut [/] faut me regarder parce que si on me regarde pas euh je vais pleurer. [You must, you must look at me because if you don't look at me, um, I'm goin' to cry.]

Here again, the deontic modality (faut) is explained and justified, but indirectly and explicitly through the predictive conditional construction (si on me regarde pas, je vais pleurer). A two-situation complex clause is set by parce que as a landmark for reinforcement of the root modality in the matrix clause. This complex process is actually rather close to the epistemic reasoning pattern described above, except that in these multi-slot constructions the complex pattern is made explicit, and that in (18) and (19) the predictive conditionals serve to justify speech acts. The complex adverbial clause thus expands from simple motivational causes to predictive and deductive detours and developments which strengthen the pragmatic 
force of her assertions and justify her intentions, actions and desires through a subjective negative evaluation of the opposite possibilities. But parce que also frequently co-occurs with a positive embedded si-clause (as in (20)) or with a quand-clause (as in (21)):

(20) MADELEINE-2;10 (Madeleine is at table and puts a bottle of Badoit in front of her plate.)

*CHI: moi j'aime bien la Badoit. [I like Badoit.]

*CHI: je mets ça là parce que moi [/] parce que si jamais j'ai soif ben j'ouvre le bouchon. [I'm putting it here because I, because if I get thirsty, well, I open the lid.]

(21) MADELEINE-2;10. (CHI smiles at OBS who is filming her.)

*OBS: pourquoi tu me fais un beau sourire comme ça [What's that lovely smile for?]

*CHI: parce que il faut faire un sourire quand on se filme. ? [because we have to smile when we're filmed.]

In these cases the pattern also marks an explicit three-term relation in a multi-clausal, double-embedded construction. These complex multiclausal patterns reveal a complex, indirect reasoning process, where the child resorts to external inferences to justify something that she is doing or intending to do. In example (21), the child feels the need to resort to and develop a general sub-rule to justify her smile: I'm smiling [Because [you have to smile when people film you]]. The use of the generic subject on in this utterance also marks the relation between what the child presents as a rule, and the justification of her own behaviour. 
This pattern of complex multi clausal constructions reveals a process of linguistic expansion from backward modalization of one situation to the expression of embedded situations which are set in a mixture of content and speech act relations. Interestingly, conditional and temporal adverbial clauses do not appear alone until later, and occur as embedded in parce que clauses in the majority of uses till 4 years old. This phenomenon is quite interesting, in view of its recurrence from $2 ; 06$ to $3 ; 00$. The data seems to show that there is a stage in Madeleine's development when she is internalizing or appropriating a set of family routines or experiential causeto-effect relations, and in order to do this, she needs to externalize them in linguistic expansion. This phenomenon can be interpreted as a link between linguistic complexification and cognitive internalization of predictive and causal relations, and a pre-requisite to the development of simpler bi-clausal structures expressing content and epistemic causes.

The process can be analysed in detail with the way Madeleine deals with the 'when climbing on a bed, take off your shoes' link. Madeleine's games and books are set on a shelf above her bed, so she can't get them without asking for help or climb onto her bed. At 2;05:

(15) MADELEINE-2;05

*CHI: je [/] je enlève mes chaussures parce que /parce que je vas bientôt attraper un jeu [I, I'm taking my shoes off because/ because I'm goin' to get a game soon.]

*MOT: ah et tu veux monter sur ton lit c'est ça ? [Oh, and you want to climb on your bed right?]

*CHI: oui [Yes] 
*MOT: ah. [Right.]

*CHI: Stéphanie enlève ses chaussures [/] ses [/] ses sandales pour attraper euh euh [Stéphanie, she takes her shoes / her sandals off to reach, um, um..]

The child relates the idea 'get a game' with 'take your shoes off' by recalling her experience of Stéphanie doing so. Her mother inserts a third term 'climb on the bed' in the inference process: get a game / climb on the bed / take shoes off. Two months later, at 2;07, when Madeleine asks her friend Lucas to take his shoes off, she has clearly internalized the intermediary cause to effect link between 'taking your shoes off' and 'climbing on her bed', and expresses it by expanding the parce que clause to a complex multi-clausal construction embedding a sinon and si-predictive construction:

(16) *CHI: mais faut qu(e) tu enlèves tes chaussures, parce que sinon si tu mets tes chaussures, ça va pas être, euh tu vas pas monter sur mon lit. [But you must take your shoes off because otherwise if you put on your shoes, it's not going to be, um, you're not going to climb on my bed.]

Yet the child's explanation remains argumentative (involving intersubjective positioning) rather than purely logical: the request for Lucas to take his shoes off (the speech act) is reinforced by the undesirable consequences of the opposite predictive proposition. Seven months later, at 3;03, the shoe-rule is developed again, in an extended multi-slot construction where all the arguments are expressed linguistically:

(17) MADELEINE-3;03 
CHI: maintenant je vais [/] je vais chercher un jeu. [Now I'm going to get a game.]

*CHI: j'enlève mes chaussures [A] parce que je vais montrer un jeu [B] parce que moi je vais monter sur mon lit [C]. [I'm taking my shoes off because I'm going to show a game, because I'm going to climb on my bed]

*CHI: et quand on monte sur un lit i faut [/] il faut euh enlever les chaussures. [And when you climb on a bed then you must take your shoes off.] *OBS: oui. [Yes]

*CHI: sinon après si on enlève pas les chaussures si j'enlève pas les chaussures, les chaussures, ça traîne partout [D]. [Otherwise then, if they don't take their shoes off, if I don't take my shoes off, shoes go all over the place!]

This long explanation combines no less than four situations (or processes): [A [parce que $\mathrm{B}$ [parce que $\mathrm{C}]$ ] et [quand $\mathrm{C}$ faut $\mathrm{A}$, sinon, [si non A, D]]]. The linear order of clauses does not correspond to the logical inference process (the order is wrong), but all the arguments are expressed (as in a jigsaw puzzle), so that her intentions to get a game is connected to a rule which she now presents as a general and necessary rule. The pronoun and determiner shift (from je to on, from mon lit to un lit) and the modal verb faut, mark the necessity of the link as in a kind of maxim. The general rule in the example is then related to her own, with a shift back from on to je and a negative evaluation of the consequences of not following the rule. 
Linguistic and experimental input is of course essential in this developmental process. Although it is impossible to track all of the input the child receives, because not everything is recorded, the longitudinal data shows that Madeleine very often takes up rules that have been expressed by her parents in previous filming sessions and integrates them into her own reasoning process. This supports the usage-based functionalist and interactionist approaches to language acquisition ${ }^{6}$ (cf. François et al., 1977; Veneziano 2009; and Bernicot et al., 2010), which consider that parent-child interactions play a very significant role in the child's linguistic complexification process. But the term 'interaction' should also refer to non-synchronic, deferred interactions, where the child analyzes and reformulates memorized argumentative input in complex constructions. This phenomenon, it should be noted, can only be analysed in longitudinal corpora.

\section{IV.2.3.3. The bi-clausal causal pattern}

Throughout Madeleine's data, $17 \%$ of the parce que clauses the child uses were coded as bi-clausal complex construction marking a content-causal relation between two independent situations (see Fig.13). In the bi-clausal content causal use [A parce que B], the adverbial clause takes up the situation in the matrix clause to link it to its 'objective', or 'real world cause' (Evers-Vermeul and Sanders 2011:1646). The two situations are thus integrated into one bi-clausal grammatical unit, synthesizing an underlying rule that no longer needs to be expanded, as in the following example at $4 ; 01:$

\footnotetext{
${ }^{6}$ As opposed to generative approaches (see general introduction, this issue).
} 
(20) CHI : elle s'est noyée parce qu'elle avait pas de brassards. [She drowned because she didn't have her arm-bands on.]

In this pattern, the matrix and subordinate verbs both express temporal situations, the subjectivity of the speaker is not a term in the clausecombining process, and discordance markers are much less frequent. Interestingly, the subject pronouns used in this pattern are mainly third person pronouns, and are in a much higher proportion compared to the backward modalization pattern and the complex multi-clausal constructions, as shown in Fig.11.

- insert Figure 11 here -

Yet even in 'content' causal relations, the use of parce que can hardly be said to mark 'objective' relations. As we have developed above, cause to effect relations are usually construed through experience in childhood, and have little to do with inherent and universal physical properties of events. Thus in the integrated content complex construction described for example (9) Elles sont tombées les feuilles parce que c'est l'automne [The leaves have fallen because it's autumn], the causal link would be better described in the Humian sense, as a cause deduced from experience rather than a truly logical and inherent physical link. The same goes for (22):

(22) MADELEINE-2;04: line 3646.

*CHI: Il a un pansement parce que il est tombé [he's got a bandage because he fell over.]

Here the child has integrated two situations into a single bi-clausal grammatical unit expressing a content-causal link between two states of affairs. However, an implicit experiential relation between falling 
over/getting hurt and getting hurt/ putting a bandage on, has been conflated into a binary relation.

\section{IV.2.4 The concertina effect}

The development of adverbial clauses in our longitudinal data of French is therefore consistent with Diessel's results on the acquisition of complex clauses as a whole in English, in so far as it confirms a general developmental path spanning from uses which elaborate on a single situation to really complex constructions where two situations are combined into one structure.

Yet our data suggests that for adverbial clauses, complexification does not proceed from a direct integration of two independent situations. Between the simple modalization of a single situation, and the integration of two situations, there seems to be an intermediate process of linear expansion through complex multi-clausal constructions, especially between $2 ; 06$ and 3;06, as shown in Fig.12 below. As analyzed above, the multi-clausal pattern enables the child to analyze and develop causal or predictive rules before synthesizing them in bi-clausal content or epistemic relations. This path of development, here called the 'concertina effect', where linguistic structures expand to more over-explicit complex syntax before contracting to more synthetic constructions, can also be observed in the development of other grammatical units, especially in the early uses French children make of relational determiners such as la fille de le monsieur before la fille $\underline{d u}$ monsieur, or le bébé de moi before mon bébé. ${ }^{7}$

\footnotetext{
${ }^{7}$ See Collombel and Morgenstern on possessive markers (this issue).
} 
The developmental path of adverbial clauses from $0 ; 10$ to $4 ; 01$ is not linear, and the concertina effect leads to diversification rather than substitution of the three construction patterns, which remain present throughout the corpus, but in different proportions. Fig. 12 shows that the backward modalization pattern is the only use the child makes of parce que clauses at the beginning, and prevails throughout the data. From 2;03 to 3;06, multi-clausal expansion develops gradually and in a higher proportion than bi-clausal complex constructions. Around the age of 3;06, the number of integrated bi-clausal constructions increases and prevails over the number of multi-clausal expanded constructions, until the diversification process is almost complete, and the occurrence of all three patterns increases around $3 ; 09$.

\section{IV.3 Parce que adverbial clauses in the input}

The observation of the input Madeleine receives in the dyadic interactions she has with her mother shows that the use of parce que is also diversified, as shown in Fig 13.

- Insert Figure 13 here -

The mother uses parce que in bi-clausal content links in higher proportion compared to Madeleine, with a ratio of about $30 \%$ of her uses of parce que. But this graph also shows that her uses remain diversified, with a majority of metalinguistic uses and backward modalization. Multi-clausal embedded uses are also present in the input, but less than in Madeleine's speech. This may be consistent with the idea that linguistic expansion of 
rules goes together with the process of internalization in child speech, and could also explain the higher proportion of integrated bi-clausal uses in the mother's speech. Besides, (see Fig. 14) the multi-clausal expanded constructions that the mother uses are not exactly the same as the ones Madeleine uses: whereas the child mainly uses parce que sinon, parce que si and parce que quand, the mother mainly uses [A parce que sinon B], [A parce que comme $\mathrm{B}, \mathrm{C}$ ], and deductive patterns such as [A parce que $\mathrm{B}$ et donc $\mathrm{C}]$.

- Insert Figure 14 here -

\section{CONCLUSIONS AND DISCUSSION}

The results obtained from the observation of Madeleine's longitudinal corpus of spontaneous French from $0 ; 10$ to $4 ; 01$ are consistent with Diessel's results on the acquisition of complex sentences in English. In particular, the four main categories of complex constructions (complement clauses, relative clauses, coordinate and adverbial clauses) in their early uses develop through a process of generalization and diversification, from pragmatic modalization of a single situation serving discursive functions, to truly bi-clausal constructions expressing a relationship between two or more situations ${ }^{8}$

The dynamic path of syntactic development and diversification of early adverbial clauses shows that the integration of independent situations is not a direct process, but goes through an intermediate phase of expansion, which probably corresponds to the cognitive internalization of cause-to-

\footnotetext{
${ }^{8}$ Although we mention some of the results here, the detailed analysis of the development of complement and relative clauses cannot be given here for lack of space, and will be presented in a future paper.
} 
effect and predictive relations through experience and input. Backward modalization constructions serving pragmatic reinforcement thus expand to multiple-embedded constructions with analytic linguistic expression of arguments, later leading to the onset of integrated content and epistemic relations in bi-clausal structures.

The analysis of Madeleine's parce que clauses using domain categorization has also yielded results that are similar to those presented in previous studies, in terms of order of domain acquisition and distribution of domains of use. Speech act uses appear first, together with content uses in answer to 'pourquoi'. Epistemic uses are acquired last and remain much less frequent than other uses. The cognitive complexity of epistemic reasoning has often been considered responsible for its late acquisition. Yet when considering the interface between grammatical and semantic complexity, we have noted a possible link between the grammatical expansion phase (which enables the child to linguistically develop complex reasoning patterns) and the subsequent appearance and higher frequency of bi-clausal epistemic uses. This suggests that the difficulty with epistemic patterns might not be their cognitive complexity, but the implicit turn of their expression in binary structures.

Finally, it can be remarked that observing early language development in children's spontaneous speech can also tell us a lot about the function of linguistic constructions and markers in synchronic linguistics. For example, the fact that the speech act use of parce que appears first, and remains prevalent in child and adult speech, supports a linguistic analysis of the conjunction as serving discourse functions and construing inter-personal 
relations. Pure logic, as we have seen when analyzing content causal relations, is probably not a linguistic phenomenon: the inter-clausal link is rarely the only relation marked by parce que. In the marker's actual use by children and adults, inter-clausal links are associated with inter-personal positioning in the interaction. The 'causal' value is therefore always tinted with subjectivity when expressed linguistically, and the conjunction reveals the speaker's standpoint in a discursive interactive progression. Parce que, like because in English (see e.g. Sekali, 1991), thus takes a value of personal justification, in a network of oppositions with other bi-clausal structures introduced by other conjunctions such as puisque, car, du coup or donc, where the inter-personal relation and role in the discourse progression is different.

This paper is a first step of a more comprehensive future study, and so far allows no possible generalization on the way all French children acquire complex sentences. Individual differences are well known, and Madeleine's data will therefore have to be compared to the other data available in the Paris Corpus in further work, in order to have a better overall comprehension of the complexification process in the acquisition of French.

\section{REFERENCES}

Bernicot, J., Veneziano, E., Muriol, M. and Bert-Erboul, A. (2010). Interactions verbales et acquisition du langage. Paris : L'Hartmattan Bowerman, M. (1979). The acquisition of complex sentences. In: P. Fletcher and M. Garman (eds), Language acquisition: Studies of First 
Language Development. Cambridge: Cambridge University Press, pp. 285-305.

Clancy, P., Jacobsen, T. and Silva, M. (1976) The acquisition of conjunction: a crosslinguistic study, Stanford Papers and Reports on Child Language, 12: 71-80.

Clancy, P., Lee, H., Zoh, M.H. (1986). Processing strategies in the acquisition of relative clauses: universal principles and languagespecific realizations, Cognition 24: 225-262.

Clark, E. (1971). On the acquisition of the meaning of before and after, Journal of Verbal Learning and Verbal Behavior, 10: 266-275.

Cristofaro, S. (2003). Subordination Strategies. A Typological Study. Oxford : Oxford University Press.

Dancygier, B., Sweetser, E. (2005). Mental Spaces in Grammar : Conditional Constructions. Cambridge: Cambridge University Press.

Diessel, H. (2004). The Acquisition of Complex Sentences. Cambridge: Cambridge University Press.

Evers-Vermeul, J., Sanders, T. (2011). Discovering domains- On the acquisition of causal connectives, Journal of Pragmatics, 43: 16451662.

Feagans, L. (1980). Children's understanding of some temporal terms denoting order, duration, and simultaneity, Journal of Psycholinguistic Research, 9: 41-57.

François, F., Francois, D., Sabeau-Joannet, E. and Sourdot, M. (1977). La syntaxe de l'enfant avant 5 ans. Paris: Larousse 
Kyratzis, A., Guo, J., Ervin-Tripp, S. (1990). Pragmatic conventions influencing children's use of causal constructions in natural discourse. In: K. Hall, J-P. Koenig, M. Meacham, S. Reinman and S. Sutton (eds), Proceedings of the $16^{\text {th }}$ Annual Meeting of the Berkeley Linguistics Society. Berkeley CA: BLS, pp.205-214.

Langacker, R. W. (1991). Foundations of Cognitive Grammar, Vol. II, Descriptive Application, Stanford : Stanford University Press.

Morgenstern, A., Sekali, M. (2009). i m'énève paque i m'énève : spécificité de l'explication verbale chez l'enfant entre 2 et 3 ans : une articulation modale, In : C. Hudelot, A. Salazar Orvig, E. Veneziano (eds.), L'explication : enjeux cognitifs et communicationnels. Leuven : Peeters, pp.125-141.

O'Grady, W. (1997). Syntactic Development. Chicago: The University of Chicago Press.

Pander Maat, H., Sanders, T. (2001). Subjectivity in causal connectives: An empirical study of language in use. Cognitive Linguistics, 12: 247273.

Piaget, J. (1948). Language and Thought in the Child. London: Routledge and Kegan Paul.

Sanders, T. (2005). Coherence, causality and cognitive complexity in discourse. In : M. Aurnague, M. Bras, A, Le Draoulec, and L. Vieu (eds), Proceedings of the First International Symposium on the exploration an modelling of meaning, SEM-05, pp. 105-114.

Sekali, M. (1991). Connexion inter-énoncés et relations intersubjectives: because, since et for, Langages $104: 62-78$. 
Sekali, M. (2010). Coordination et dynamique discursive : étude comparative des coordonnants anglais and, or, but et for, In: Florea, Papahagi, Pop, and Curea (eds), Directions Actuelles en Linguistique du Texte. Cluj-Napoca : Casa Cărţii de Ştiinţă, pp. 235-245.

Slobin, D. (1997). The origins of grammaticizable notions: beyond the indidivual mind, In: D. Slobin (ed.), The Crosslinguistic Study of Language Acquisition, Vol. V, Expanding the Context. London: Lawrence Erlbaum, pp. 265-323.

Sweetser, E. (1990). From Etymology to Pragmatics. Metaphorical and Cultural Aspects of Semantic Structure, Cambridge: Cambridge University Press.

Tomasello, M. (2003). Constructing a Language: A Usage-Based Theory of Language Acquisition. Cambridge US : Harvard University Press.

Veneziano, E. (2009). Emergence des conduites explicatives dans l'interaction naturelle mère-enfant: méthodes d'analyse et modèle d'acquisition basé sur les situations conflictuelles, In: C. Hudelot, A. Salazar Orvig, E. Veneziano (eds.), L'explication : enjeux cognitifs et communicationnels. Leuven : Peeters, pp. 151-173.

Zufferey S. (2006). Connecteurs pragmatiques et métareprésentation : l'exemple de parce que. Cahiers de linguistique française, 27 : 161179.

Number of words with references: 8937

Total number of words (including abstract and figures): 9515

Manuscript after revision: July $14^{\text {th }} 2011$ 


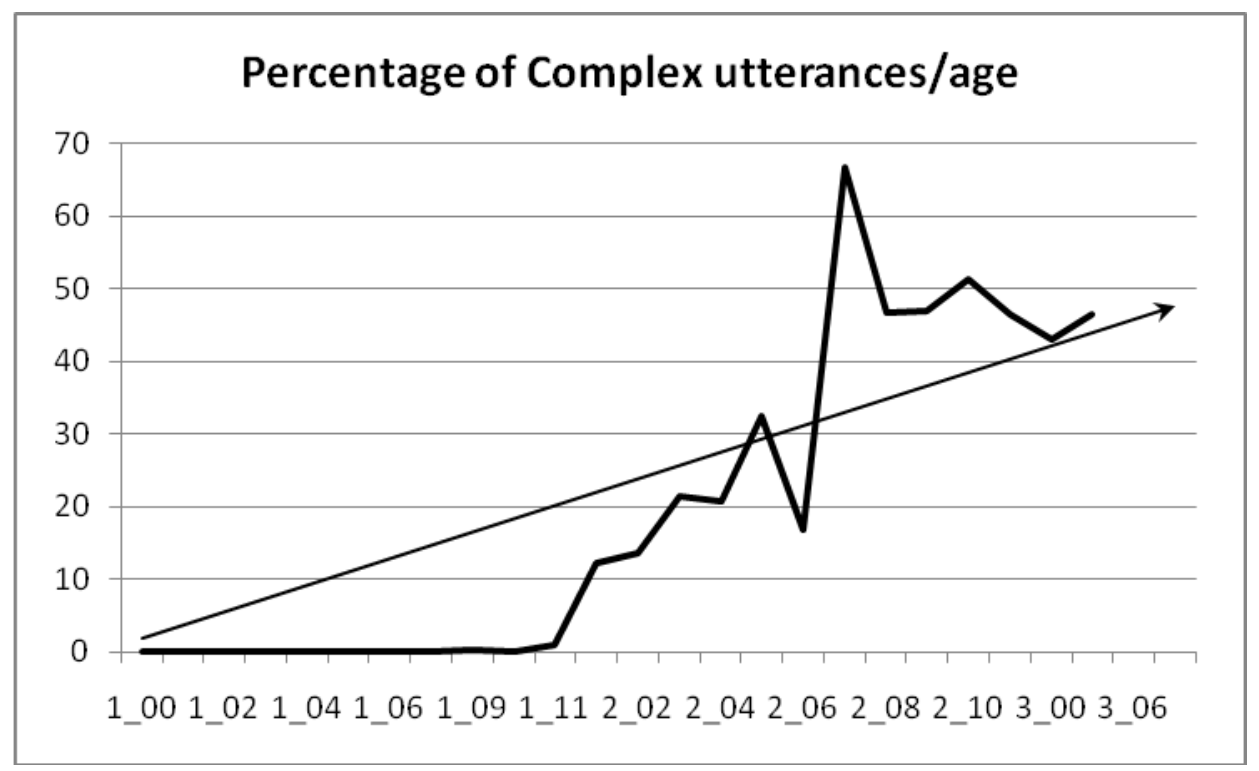

Figure 1: Percentage of complex utterances over the total number of utterances each month 


\begin{tabular}{|l|l|}
\hline Age & First appearance \\
\hline $\mathbf{1 ; 0 7}$ & Formulaic $E T$ linking NPs (N et N) \\
\hline $1 ; 08$ & \\
\hline $1 ; 09$ & Infinitival Complements \\
\hline $1 ; 10$ & $\begin{array}{l}\text { Non formulaic N } E T \text { N } \\
\text { Non finite POUR-intention adverbial } \\
\text { clause } \\
\text { Formulaic Cleft sentences }\end{array}$ \\
\hline $\mathbf{1 ; 1 1}$ & $\begin{array}{l}\text { Inter-clausal } \boldsymbol{E T} \\
\text { PARCE QUE/ SI }\end{array}$ \\
\hline $\mathbf{2 ; 0 1}$ & Relative Clauses \\
\hline $2 ; 03$ & QUAND / Finite complement clauses \\
\hline $\mathbf{2 ; 0 4}$ & MAIS/ OU / DONC/ DU COUP \\
\hline $\mathbf{2 ; 0 5}$ & JUSQU'A CE $Q U E$ \\
\hline $2 ; 08$ & PUISQUE \\
\hline $2 ; 11$ & Causal COMME \\
\hline $3 ; 06$ & \\
\hline
\end{tabular}

Figure 2: First appearance of conjunctions and subordinate clause types 


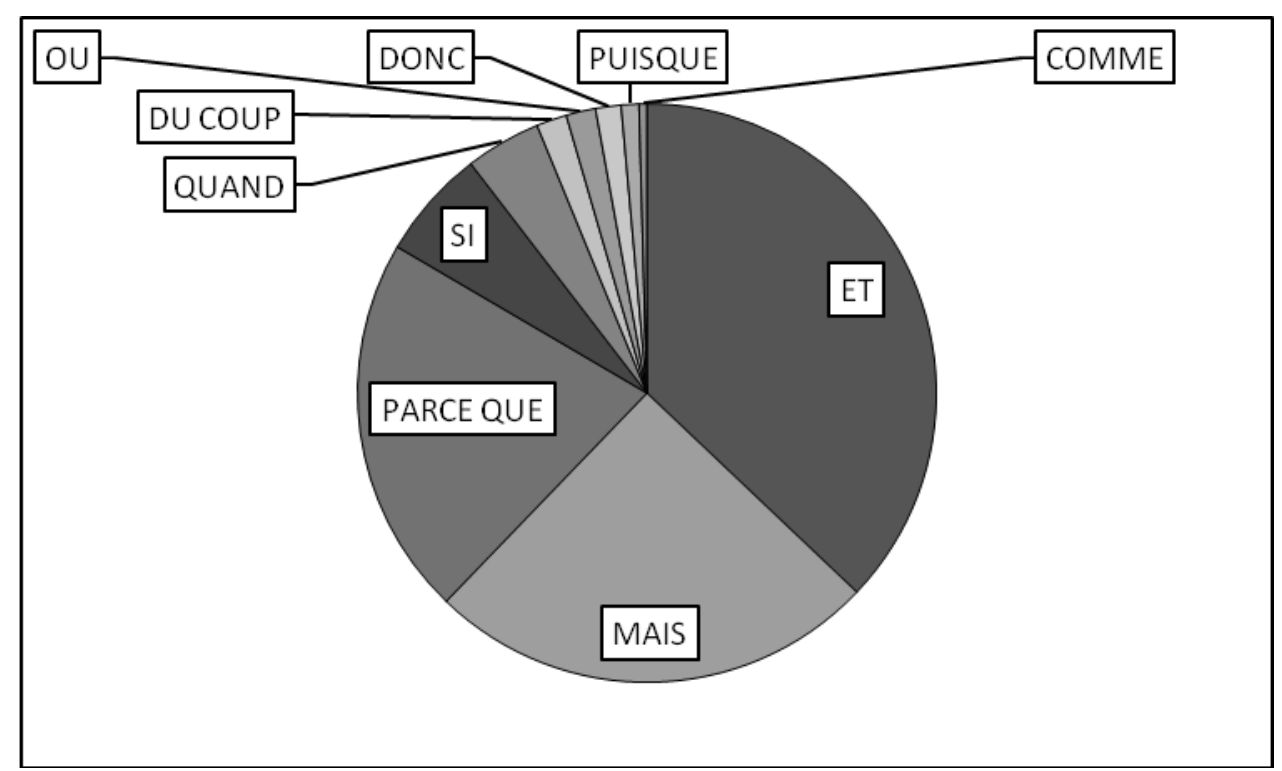

Figure 3: Distribution of conjunctions across the corpus $(1 ; 11-4 ; 01)$ 


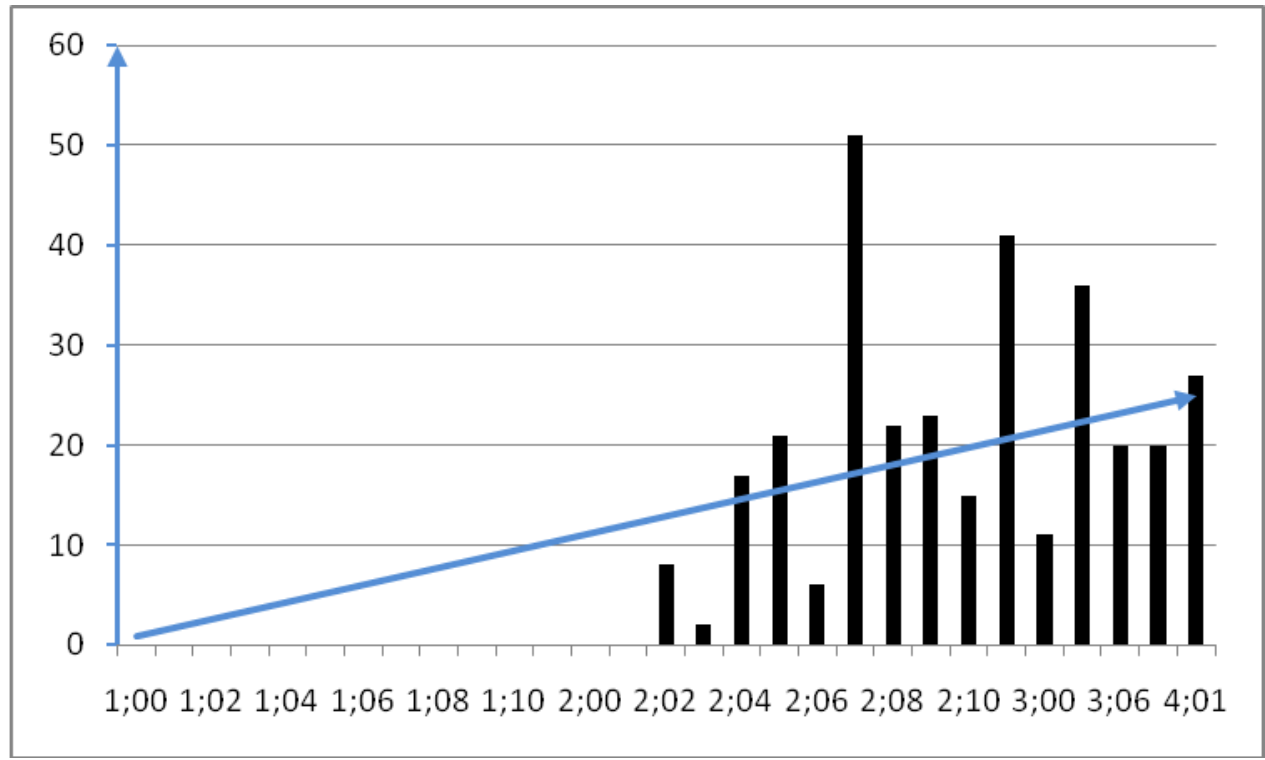

Figure 4: Total number of parce que clauses by age 


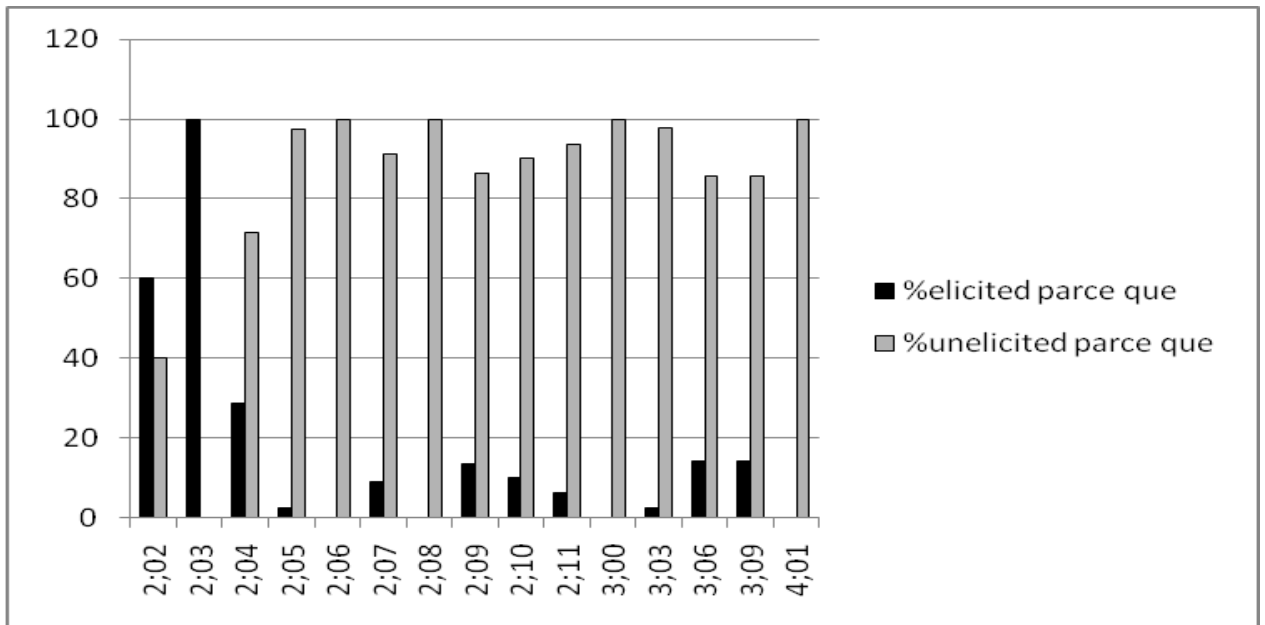

Figure 5: Percentage of parce que constructions in answer to pourquoi? 


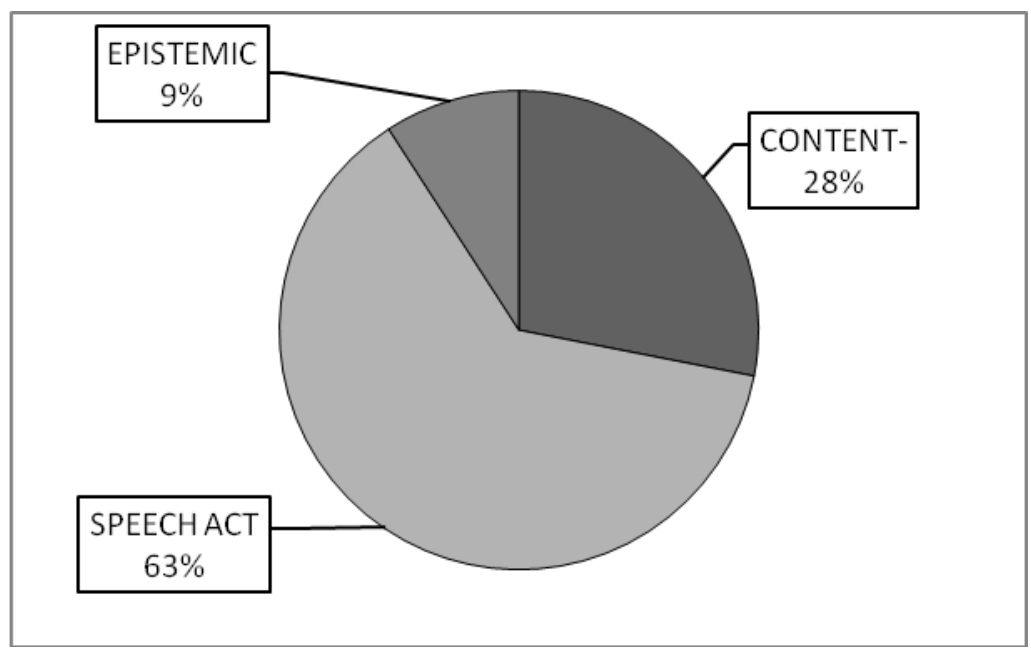

Figure 6: Distribution of causal domains across the data 


\begin{tabular}{|l|r|r|r|}
\hline age & CONTENT & SPEECH ACT & EPISTEMIC \\
\hline $\mathbf{2 ; 0 2}$ & 6 & 2 & 0 \\
\hline $\mathbf{2 ; 0 3}$ & 1 & 1 & 0 \\
\hline $\mathbf{2 ; 0 4}$ & 7 & 7 & 1 \\
\hline $\mathbf{2 ; 0 5}$ & 2 & 19 & 0 \\
\hline $\mathbf{2 ; 0 6}$ & 2 & 3 & 1 \\
\hline $\mathbf{2 ; 0 7}$ & 4 & 46 & 1 \\
\hline $\mathbf{2 ; 0 8}$ & 4 & 18 & 0 \\
\hline $\mathbf{2 ; 0 9}$ & 7 & 12 & 2 \\
\hline $\mathbf{2 ; 1 0}$ & 5 & 9 & 1 \\
\hline $\mathbf{2 ; 1 1}$ & 5 & 35 & 1 \\
\hline $\mathbf{3 ; 0 0}$ & 5 & 6 & 0 \\
\hline $\mathbf{3 ; 0 3}$ & 11 & 19 & 6 \\
\hline $\mathbf{3 ; 0 6}$ & 12 & 3 & 5 \\
\hline $\mathbf{3 ; 0 9}$ & 8 & 7 & 5 \\
\hline $\mathbf{4 ; 0 1}$ & 10 & 12 & 6 \\
\hline
\end{tabular}

Fig. 7: Distribution of domains of parce que uses /age 


\begin{tabular}{|c|c|c|c|}
\hline Patterns & $\begin{array}{c}\text { Backward } \\
\text { modalization }\end{array}$ & $\begin{array}{c}\text { Complex multi- } \\
\text { clausal }\end{array}$ & $\begin{array}{c}\text { Biclausal } \\
\text { Integration }\end{array}$ \\
\hline Grammatical & 1 situation & $\begin{array}{c}2 \text { or more } \\
\text { situations } \\
\text { complexity }\end{array}$ & $\begin{array}{c}\text { 2 situations in } \\
\text { one grammatical } \\
\text { unit }\end{array}$ \\
\hline $\begin{array}{c}\text { Semantic } \\
\text { complexity }\end{array}$ & Speech act link & $\begin{array}{c}\text { Mixed domain- } \\
\text { links } \\
\text { (content/speech } \\
\text { act/epistemic) }\end{array}$ & Content link \\
\hline
\end{tabular}

Fig. 8: Cross-categorization of parce que sub-patterns 


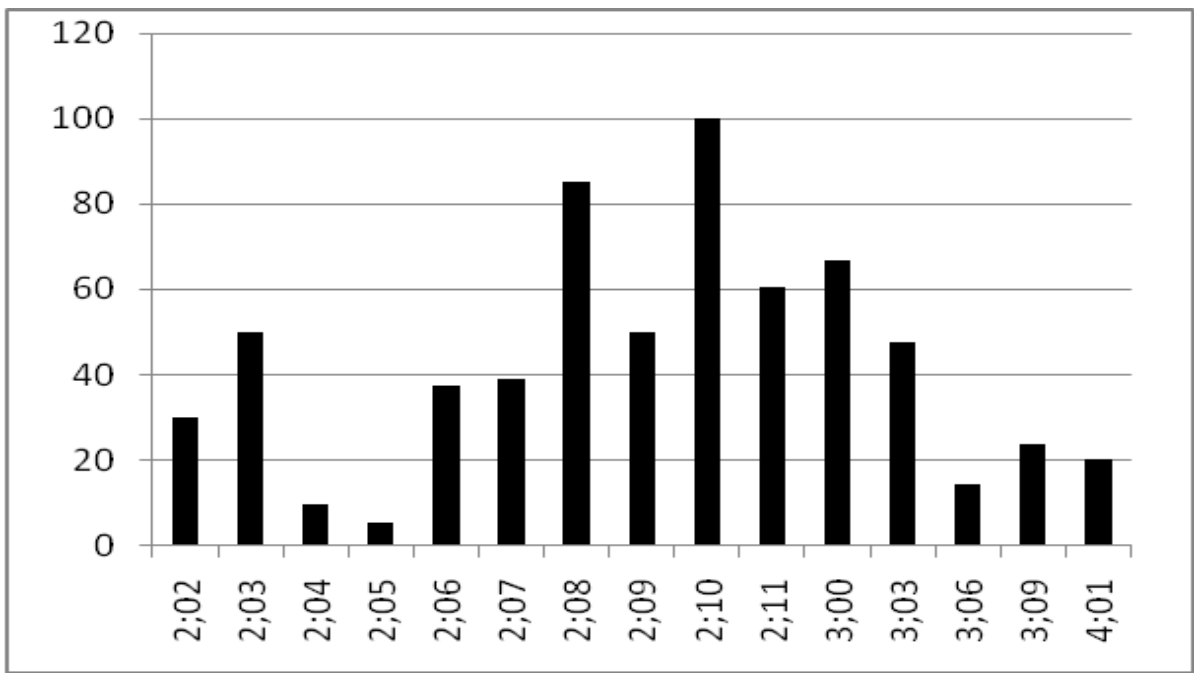

Figure 9: Percentage of parce que constructions with discordance markers 


\begin{tabular}{|c|c|c|c|c|}
\hline age & $\begin{array}{l}\text { Backward } \\
\text { modalization } \\
\text { ( } 1 \text { SIT) }\end{array}$ & \begin{tabular}{|l|} 
Complex \\
Multi- \\
clausal \\
EXPANSION
\end{tabular} & $\begin{array}{l}\text { Bi-clausal } \\
2 \text { SIT } \\
\text { INTEGRATION } \\
\end{array}$ & $\begin{array}{l}\text { Total } \\
\text { PARCE QUE }\end{array}$ \\
\hline $2 ; 02$ & 8 & 0 & 0 & 8 \\
\hline 2;03 & 2 & 0 & 0 & 2 \\
\hline 2;04 & 8 & 3 & 4 & 15 \\
\hline 2;05 & 18 & 1 & 2 & 21 \\
\hline 2;06 & 3 & 2 & 1 & 6 \\
\hline 2;07 & 42 & 7 & 2 & 51 \\
\hline 2;08 & 14 & 6 & 2 & 22 \\
\hline 2;09 & 15 & 4 & 2 & 21 \\
\hline $2 ; 10$ & 8 & 5 & 2 & 15 \\
\hline 2;11 & 33 & 5 & 4 & 42 \\
\hline $3 ; 00$ & 5 & 3 & 3 & 11 \\
\hline 3;03 & 22 & 6 & 8 & 36 \\
\hline 3;06 & 7 & 5 & 8 & 20 \\
\hline 3;09 & 9 & 4 & 7 & 20 \\
\hline $4 ; 01$ & 16 & 3 & 9 & 28 \\
\hline total & 210 & 54 & 53 & 317 \\
\hline
\end{tabular}

Fig. 10: Parce que grammatical patterns/age 


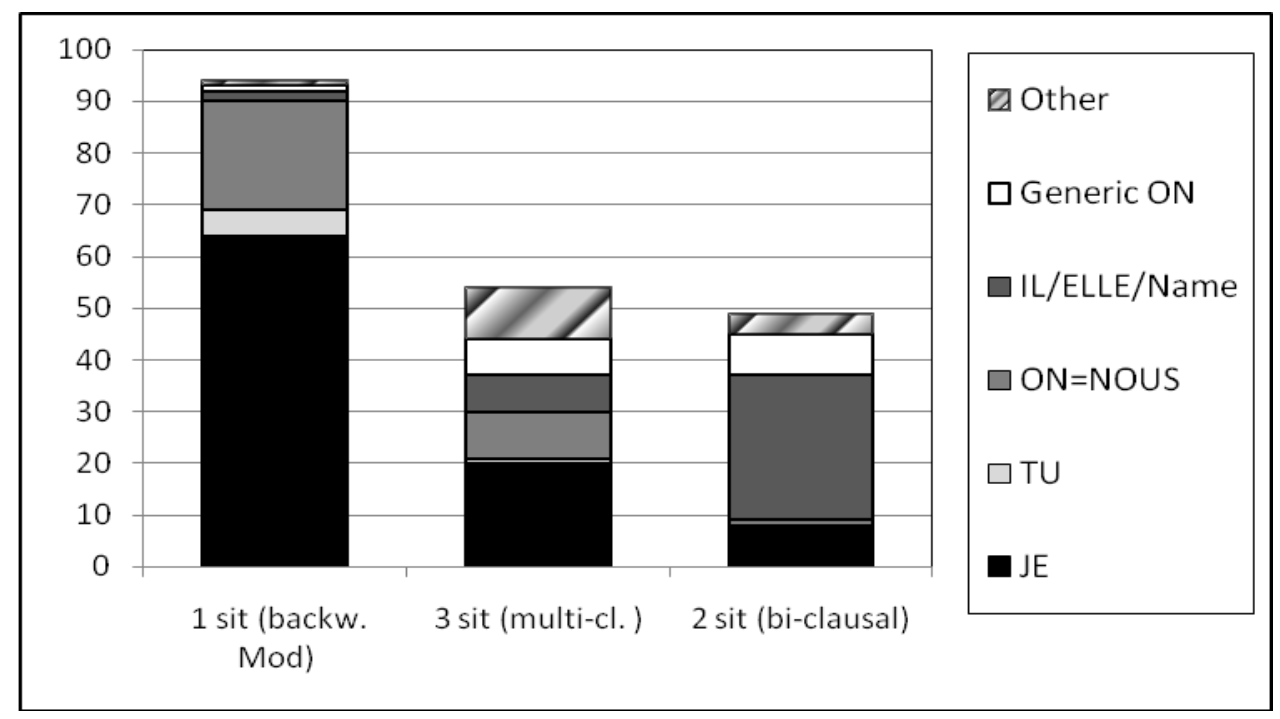

Figure 11: Relative proportion of subject pronouns used in parce que adverbial clauses 


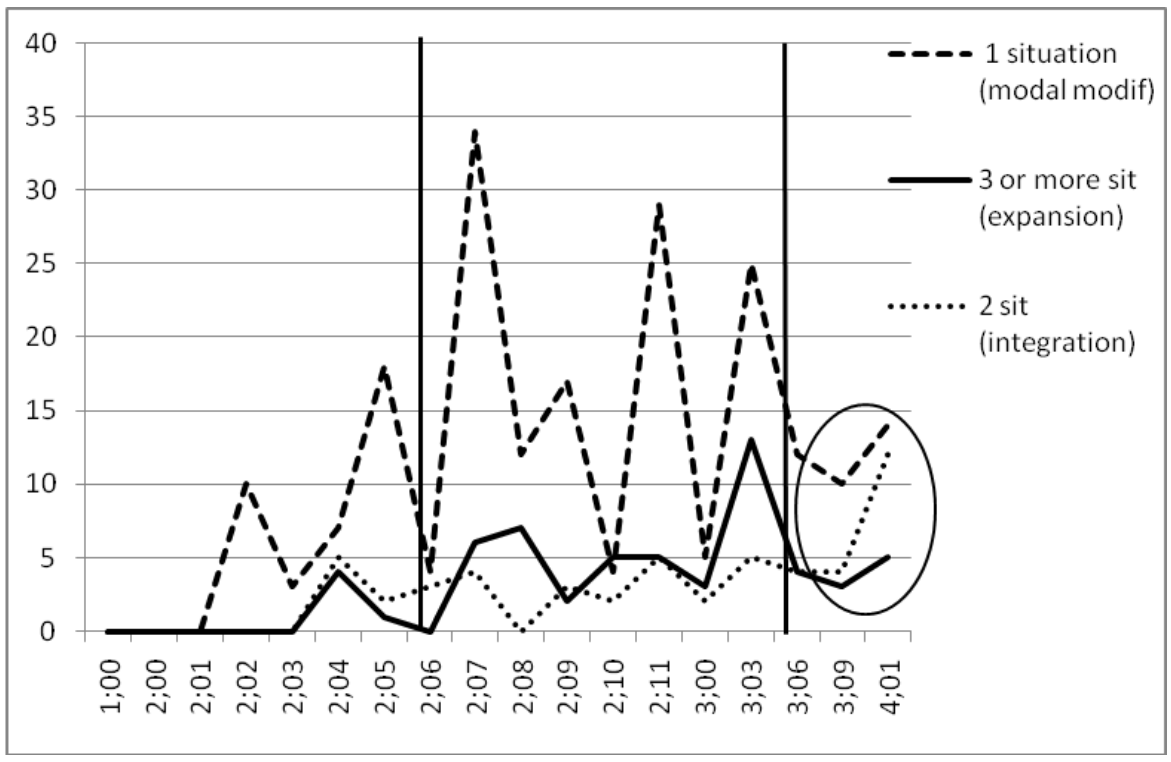

Figure 12: Number of occurrences of sub-patterns of parce que clauses / age 


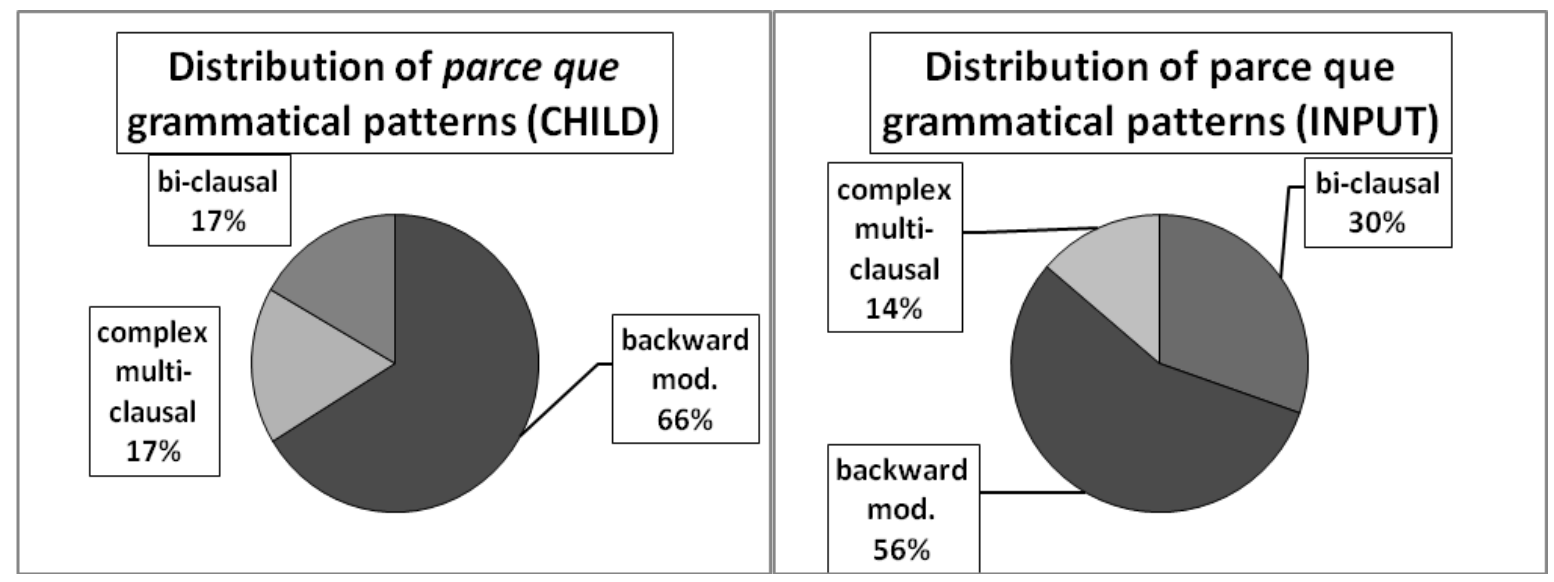

Figure 13: Distribution of parce que grammatical patterns child / input 


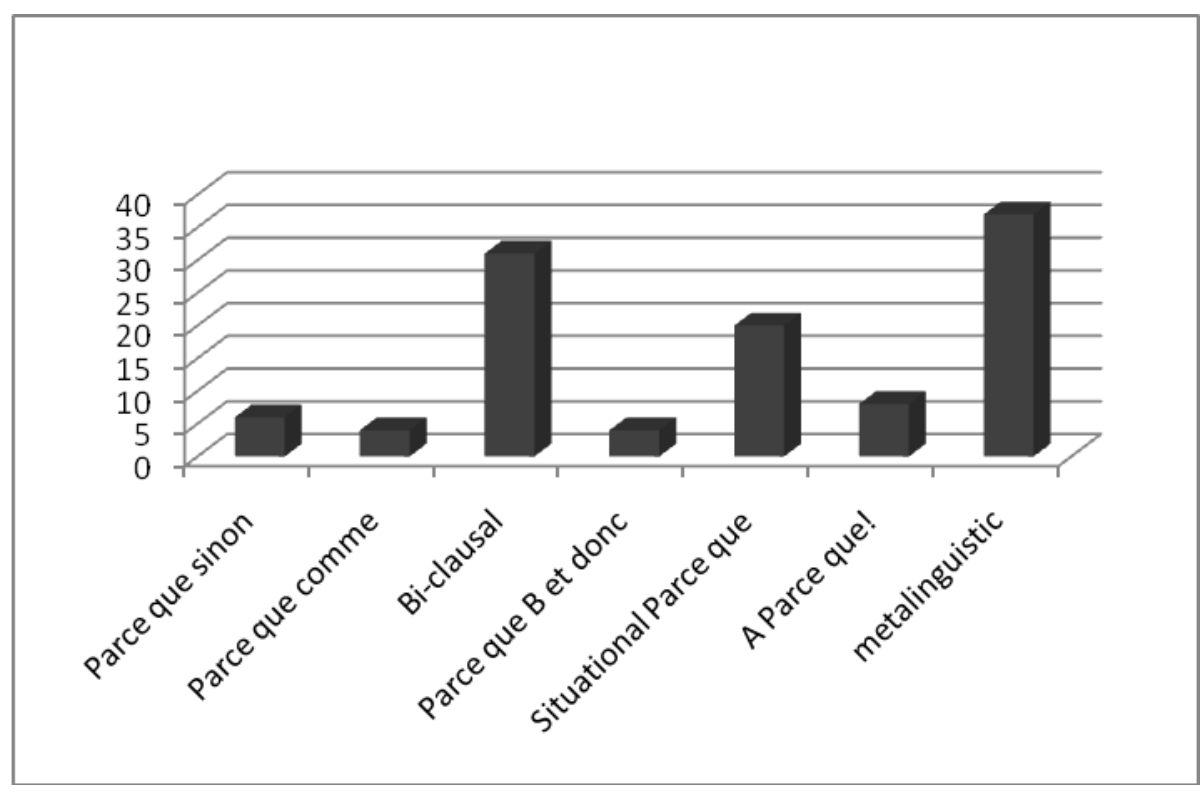

Figure 14: Percentage of various parce que patterns in the input 